\title{
The Production and Growth Characteristics of Yeast and Mycelial Forms of Candida albicans in Continuous Culture
}

\author{
By M. G. SHEPHERD AND P. A. SULLIVAN \\ Department of Biochemistry, University of Otago, Dunedin, New Zealand
}

(Received II August 1975; revised I4 October 1975)

\section{SUMMAR Y}

The growth characteristics of Candida albicans CMI45,348 have been examined under aerobic conditions in continuous culture. At different steady states the environment was controlled with respect to the concentrations of dissolved oxygen, carbon and nitrogen, the $\mathrm{pH}$, and the temperature. Dry matter, substrate concentration, yield, specific oxygen uptake, specific carbon dioxide release and respiration quotient were examined as a function of the dilution rate. The morphology depended on the carbon source. Maltose produced a mycelial morphology, whereas with lactate a yeast culture was obtained. With fructose or glucose as a carbon source a mixed morphology of yeast, pseudo-mycelial and mycelial forms was produced. A large number of different growth conditions were examined in batch culture but a mixed morphology was always obtained.

\section{INTRODUCTION}

The reversible transition from a yeast habit of growth to a mycelial one is well documented for a number of fungi. For Candida albicans a large number of different conditions and media have been described for producing the yeast-to-mycelial transition (Romano, I966; Bartnicki-Garcia \& McMurrough, I97I). In most of these studies, however, a nonsynthetic medium was used and mixed populations of yeast, mycelial and pseudo-mycelial forms were obtained. A defined medium for the production of mycelial and yeast forms has been described (Marriott, I975) and Simonetti, Strippoli \& Cassone (1974) described a simple method for the production of germ tubes.

Despite the importance of $C$. albicans as a human pathogen, there are few reported studies on the intermediary metabolism and growth characteristics of this organism (Chattaway et al., 1973; Ward \& Nickerson, 1958). To determine the biochemical factors that decide whether $C$. albicans grows in a mycelial or yeast form it is necessary to use a system where different physiological growth states are readily reproduced and where large quantities of yeast and mycelial cells can be obtained. Previously, yeast and mycelial forms of C. albicans have been obtained in shake cultures, but the lack of reproducibility promoted the present study. The use of the chemostat satisfies two requirements: it provides an analytical system for the study of growth characteristics, and of large quantities of yeast and mycelial cells grown under reproducible conditions. This paper describes the production and growth characteristics of yeast and mycelial forms of C. albicans (CMI45,348).

\section{METHODS}

Reagents. All chemicals were analytical reagent grade. Enzyme substrates and other biological substances were obtained from the Sigma.

Organisms and culture conditions. The strain of Candida albicans used was CMI45,348, 
obtained from the Commonwealth Mycological Institute, Surrey. Fungi were propagated on either Sabouraud dextrose agar or malt extract agar at $28{ }^{\circ} \mathrm{C}$.

Two basic media were used. $\mathrm{N}$-limiting medium contained (per litre): carbon source, I5 g; $\left(\mathrm{NH}_{4}\right)_{2} \mathrm{SO}_{4}, 0.5 \mathrm{~g} ; \mathrm{KH}_{2} \mathrm{PO}_{4}, 2.0 \mathrm{~g} ; \mathrm{CaCl}_{2} .2 \mathrm{H}_{2} \mathrm{O}, 0.05 \mathrm{~g} ; \mathrm{MgSO}_{4} .7 \mathrm{H}_{2} \mathrm{O}, 0.05 \mathrm{~g}$; $\mathrm{ZnSO}_{4} \cdot 7 \mathrm{H}_{2} \mathrm{O}$, I mg; $\mathrm{CuSO}_{4} \cdot 5 \mathrm{H}_{2} \mathrm{O}$, I mg; $\mathrm{FeSO}_{4} \cdot 7 \mathrm{H}_{2} \mathrm{O}$, 0.0I g; biotin, $25 \mu \mathrm{g}$; final pH $5 \cdot 2$. C-limiting medium contained (per litre): carbon source, IO g; $\left(\mathrm{NH}_{4}\right)_{2} \mathrm{SO}_{4}, 2 \mathrm{~g} ; \mathrm{KH}_{2} \mathrm{PO}_{4}$, $2.0 \mathrm{~g} ; \mathrm{CaCl}_{2} .2 \mathrm{H}_{2} \mathrm{O}, 0.05 \mathrm{~g} ; \mathrm{MgSO}_{4} .7 \mathrm{H}_{2} \mathrm{O}, 0.05 \mathrm{~g} ; \mathrm{ZnSO}_{4} .7 \mathrm{H}_{2} \mathrm{O}$, I mg; $\mathrm{CuSO}_{4} .5 \mathrm{H}_{2} \mathrm{O}$, I $\mathrm{mg} ; \mathrm{FeSO}_{4} \cdot 7 \mathrm{H}_{2} \mathrm{O}$, o.0 I g; biotin, $25 \mu \mathrm{g}$; final $\mathrm{pH} 5 \cdot 2$.

Slants ( $8 \mathrm{~g}$ vials) of $C$. albicans were shaken with $5 \mathrm{ml}$ of Tween 80 solution (500 p.p.m.). This produced a suspension containing approximately $5 \times 10^{8}$ cells which was used to inoculate the fermenter.

Shake culture experiments. To determine the growth characteristics of C. albicans CMI 45,348 in submerged culture, a 21 Erlenmeyer flask containing I 1 C-limiting medium with glucose as carbon source, was inoculated with $5 \times 10^{8}$ cells and shaken on a gyratory shaker at $250 \mathrm{rev}$./min at $28^{\circ} \mathrm{C}$; this flask was modified with three vertical flutes to improve aeration.

The effects of different media on the morphology of $C$. albicans grown in submerged culture were examined as follows. Suspensions containing $10^{8}$ cells were added to $250 \mathrm{ml}$ Erlenmeyer flasks containing $100 \mathrm{ml}$ of the appropriate medium, and then shaken at $250 \mathrm{rev} . / \mathrm{min}$ at $28^{\circ} \mathrm{C}$. After $24 \mathrm{~h}$, the morphology was examined by phase-contrast microscopy.

Chemostat studies. The chemostat was designed and constructed in the School of Biotechnology, University of New South Wales, Kensington, Australia. It had a culture volume capacity of $\mathrm{I} l$ and was equipped with automatic recording and control of $\mathrm{pH}$ and temperature; mixing was achieved with a Vibromix (Chemap, Mannedorf, Switzerland). The organism was grown in either a nitrogen- $\left[\right.$ as $\left.\left(\mathrm{NH}_{4}\right)_{2} \mathrm{SO}_{4}\right]$ or carbon- [as glucose, lactate, succinate, fructose or maltose] limited medium. The organism could be maintained in steadystate growth at any $\mathrm{pH}$ between 2.0 and 8.0 in the medium described, by the addition of either $2 \mathrm{M}-\mathrm{NaOH}$ or $2 \mathrm{M}-\mathrm{HCl}$. The temperature of growth, unless otherwise specified, was $30 \pm 0 \cdot \mathrm{I}{ }^{\circ} \mathrm{C}$. The air flow and the stirrer were adjusted to provide a $P_{\mathrm{O}_{2}}$ (determined by a Johnson-type steam-sterilizable oxygen electrode; Johnson, Borkowski \& Engblom, 1964) between 5 and $90 \%$ saturation of oxygen. The culture was regarded as having attained a steady state following a change in operating conditions when it had grown for at least seven doubling times, or for at least two doubling times during which there was no change in the monitored parameters of growth, i.e. $E_{540}, P_{\mathrm{O}_{2}}$ of the culture, $P_{\mathrm{CO}_{2}}$ of the effluent gas (determined in a Lira model 303 infrared analyzer; Mine Safety Appliances Co. Ltd, Glasgow), or concentration of one of the substrates. Where a change in morphology occurred it took 12 or more doubling times for a steady state to be achieved.

Analytical methods. The fungal cell dry matter was determined from the $E_{540}$ of a sample by using a calibration curve of $E_{540}$ versus dry weight. Separate calibration curves for mycelial, pseudo-mycelial and yeast cells of $C$. albicans $\mathrm{CMI} 45,348$ were required. Glucose concentrations were determined by the glucose oxidase method (Lloyd \& Whelan, I969). Maltose was determined with 3,5-dinitrosalicylic acid reagent (Pettersson \& Porath, 1966). Lactate was estimated colorimetrically by the method of Barker (1957). The micro-Kjeldahl method was used for nitrogen estimation (Ballentine, 1957).

Oxygen uptake measurements. The oxygen uptake rates of freshly harvested cells were measured in a Clark-type oxygen electrode (Yellow Springs Instrument Co., Ohio, U.S.A.; electrode 533I). Where necessary the sample was diluted with spent medium obtained just before the oxygen uptake determination. A Thermox Oxygen Analyzer (Thermolab 


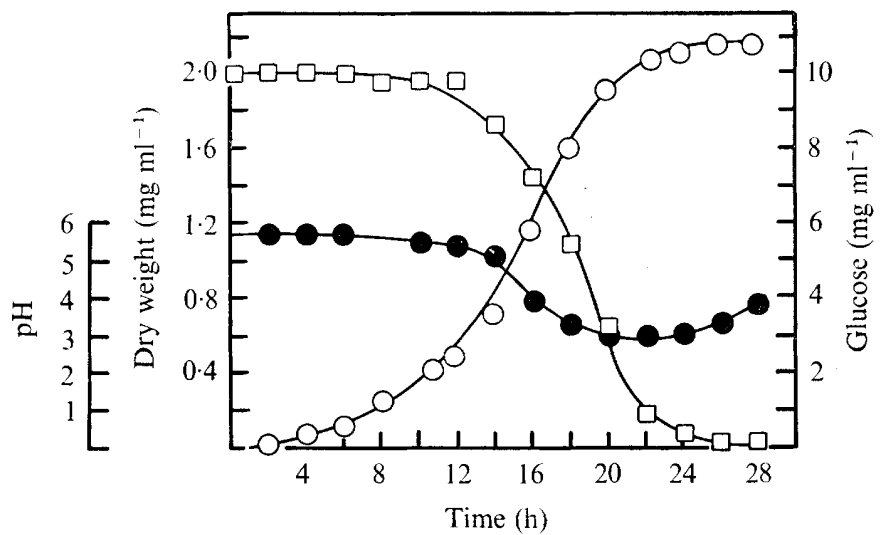

Fig. I. Growth characteristics of $C$. albicans CMI45,348 in submerged culture. Candida albicans was grown in a 21 Erlemneyer flask as described in Methods. Samples ( $10 \mathrm{ml}$ ) were removed at $2 \mathrm{~h}$ intervals and analysed for $(\bigcirc)$ dry weight, $(\square)$ glucose concentration, and $(\bullet) \mathrm{pH}$.

Table I. The effect of carbon source on the morphology of C. albicans CMI45,348 grown in shake culture

Erlenmeyer flasks $(250 \mathrm{ml})$ containing $100 \mathrm{ml}$ of $\mathrm{N}$-limiting medium were shaken on a gyratory shaker at $250 \mathrm{rev} . / \mathrm{min}, 28^{\circ} \mathrm{C}$, with $\mathrm{I} \%(\mathrm{w} / \mathrm{v})$ of the carbon sources indicated below. The morphology was examined with phase-contrast microscopy after $24 \mathrm{~h}$.

$\left.\begin{array}{ll}\begin{array}{ll}\text { Carbon source } \\ \text { Glucose } \\ \text { Galactose }\end{array} \\ \text { Succinate } \\ \text { Acetate } \\ \text { Lactate } \\ \text { Maltose } \\ \text { Sucrose }\end{array}\right\}$

Morphology

Pseudo-mycelial; some yeast cells

Mixture of yeast and pseudo-mycelial

Mixture of mycelial and pseudo-mycelial

Instruments, Inc., Pittsburgh, Pennsylvania, U.S.A.) was used for oxygen analysis in the gas stream towards the end of the study.

Metabolic quotients. The specific growth rate, $\mu$, of the steady-state continuous culture is equal to the dilution rate, $D$, and is expressed in units of reciprocal time $\left(\mathrm{h}^{-1}\right)$. The specific rate of substrate utilization $\left(Q_{\text {substrate }}\right)$ was calculated as $\mu\left(S_{0}-S\right) / X$, where $S_{0}$ is the original substrate concentration in the feed solution $(\mathrm{g} / \mathrm{l})$, and $S$ and $X$ are the steadystate values of the substrate level in the culture $(\mathrm{g} / \mathrm{l})$ and fungal dry weight $(\mathrm{g} / \mathrm{l})$, respectively. The $Q_{\text {substrate }}$ is therefore expressed as g substrate (g dry wt) $)^{-1} \mathrm{~h}^{-1}$. The specific oxygen uptake and specific carbon dioxide release are expressed as mmol gas (g dry wt) ${ }^{-1} \mathrm{~h}^{-1}$.

\section{RESULTS}

\section{Shake culture experiments}

We tested the effect of a variety of additives on the morphology of $C$. albicans CMI45,348. This strain was chosen because it grew in a shake culture of glucose salts medium with a mixed mycelial, pseudo-mycelial (Morris, 1966) and yeast morphology. The growth characteristics of $C$. albicans CMI45,348 grown on glucose in a shake flask are shown in Fig. I.

Table I shows the effect of carbon source on the morphology of $C$. albicans. In shake flask 
experiments using $\mathrm{N}$-limiting medium with glucose as carbon source, the $\left(\mathrm{NH}_{4}\right)_{2} \mathrm{SO}_{4}$ concentration was varied from $\mathrm{O} \cdot \mathrm{I}$ to $4 \mathrm{~g} / \mathrm{l}$. At low concentrations of $\left(\mathrm{NH}_{4}\right)_{2} \mathrm{SO}_{4}$, pseudomycelial cells predominated after $24 \mathrm{~h}$, but as the concentration of the $\left(\mathrm{NH}_{4}\right)_{2} \mathrm{SO}_{4}$ was increased there was a small increase in the proportion of yeast cells. Mardon, Balish \& Phillips (I969) reported that ammonium salts as nitrogen source promoted yeast-like growth of a variant strain of $C$. albicans. Cysteine was added to C-limiting medium, with glucose as carbon source, at final concentrations of I, IO, 50 and $100 \mathrm{mM}$. There was inhibition of growth at concentrations greater than $10 \mathrm{~mm}$ and in these cases the morphology was examined for up to $72 \mathrm{~h}$ of growth. The higher the concentration of cysteine the more yeast cells were present, although the actual number of yeast cells varied from experiment to experiment. Cysteine has been extensively used to suppress filamentous growth of C. albicans (Nickerson \& Mankowski, 1953).

Using C-limiting medium, with glucose as the carbon source, the following compounds, at the final concentrations given, had no significant effect on the morphology: manganese (I $\mu \mathrm{M}$, Io $\mu \mathrm{M}$, I00 $\mu \mathrm{M}$ and $\mathrm{I} \mathrm{mM}$ ), methionine (Io $\mathrm{mM}, \mathrm{I} 00 \mathrm{mM}$ ), phenethyl alcohol (0.1 \%). It has been reported that methionine stimulated filamentous growth of C. albicans (Mardon et al., 1969), while phenethyl alcohol and $\mathrm{Mn}^{2+}$ influence the morphology of Mucor species (Terenzi \& Storck, I968; Bartnicki-Garcia \& Nickerson, 1962).

Several other media were tried at both 28 and $37^{\circ} \mathrm{C}$. These include: GGY (glucose, Io g; glycine, Io g; yeast extract, $\mathrm{I} \cdot \mathrm{og}$; distilled water $\mathrm{I} 1$ ) at final $\mathrm{pH}$ values of $5,6,7,7.5$ and 8; GGY plus $10 \%$ serum; GGY plus $0.5 \%$ inositol; soluble starch $(0.5 \%)$ in place of glucose in GGY; glutamine ( $0.1 \%$ ) in place of glycine in GGY; and Dulbecco's modified Eagle medium (Grand Island Biological Co., Schipol-East, The Netherlands). Glycine (Mardon et al., 1969), yeast extract (Yamaguichi, I974), serum (Taschdjian, Burchall \& Kozinn, I960), and soluble starch (Nickerson \& Mankowski, I953) have been used to cause filamentous growth. Inositol (Brown \& Hough, 1965) affects the morphology of Saccharomyces cerivisiae, while temperature-dependent dimorphism of $C$. albicans has been reported with growth on tissue culture medium (Dabrowa et al., 1970) and on basal medium (Chattaway, Holmes \& Barlow, I968). No batch system was found which would produce a complete yeast or mycelial culture; there was always a mixed morphology of yeast, pseudo-mycelial and mycelial cells. All cultures were examined at 24,48 and $72 \mathrm{~h}$, but the age of the culture had very little effect on the morphology. A disturbing feature of these experiments was the lack of reproducibility, and this was a principal factor in promoting the chemostat studies.

The size of the inoculum appeared to affect the morphology; generally a small inoculum $\left(<10^{7}\right.$ cells) increased the mycelial content while an inoculum of $10^{8}$ cells or greater produced a higher proportion of yeast cells.

\section{Continuous culture studies}

In the chemostat, the morphology of $C$. albicans CMI45,348 depended on the carbon source. The morphology was not markedly affected by varying the $\mathrm{pH}$ or the dilution rate. For any particular carbon source the morphology was the same whether the system was limiting with respect to nitrogen or carbon. A mixed morphology was obtained with glucose, fructose and succinate. Steady states were obtained with $\mu$ values between 0.05 and 0.2 , and maximum growth rates of $0.30,0.22$ and 0.18 were obtained for glucose, fructose and succinate, respectively.

With lactate as carbon source a yeast culture was obtained, while a mycelial morphology resulted from the use of maltose as a carbon source. When shake flasks with glucose as the carbon source were inoculated and incubated with either the mycelial culture resulting from 
Table 2. Growth characteristics of C. albicans grown on maltose in continuous culture

Culture medium was as described in the text for maltose-limited growth. Steady-state values for dry matter $(X)$, maltose $(S)$, yield $(Y)$, specific rate of maltose utilization $\left[Q_{\text {maltose }}\right.$ in $\left.\mathrm{g}(\mathrm{g} \text { dry wt) })^{-1} \mathrm{~h}^{-1}\right]$, specific oxygen uptake $\left(Q_{\mathrm{O}_{2}}\right.$ in $\left.\mathrm{mmol} \mathrm{O}_{2} \mathrm{~g}^{-1} \mathrm{~h}^{-1}\right)$, specific carbon dioxide release $\left(Q_{\mathrm{CO}_{2}}\right.$ in mmol $\mathrm{CO}_{2} \mathrm{~g}^{-1} \mathrm{~h}^{-1}$ ) and the respiration quotient (RQ) are given as a function of the dilution rate $D$.

\begin{tabular}{|c|c|c|c|c|c|c|c|c|}
\hline$\underset{\left(\mathrm{h}^{-1}\right)}{D}$ & $\begin{array}{c}\text { Final } \\
\mathrm{pH}\end{array}$ & $\underset{(\mathrm{g} / \mathrm{l})}{X}$ & $\underset{(\mathrm{g} / \mathrm{l})}{S}$ & $\begin{array}{c}Y \\
\left(X \mid S_{0}-S\right)\end{array}$ & $Q_{\text {maltose }}$ & $Q_{\mathrm{o}_{2}}$ & $Q_{\mathrm{CO}_{2}}$ & $\mathrm{RQ}$ \\
\hline 0.08 & $2 \cdot 7$ & 3.65 & 0.04 & 0.37 & 0.22 & $2 \cdot 2$ & $2 \cdot 0$ & 0.94 \\
\hline 0.09 & $2 \cdot 7$ & 3.75 & 0.07 & 0.38 & $0 \cdot 24$ & $2 \cdot 2$ & $2 \cdot I$ & 0.94 \\
\hline O. I I & $2 \cdot 8$ & $3 \cdot 80$ & 0.03 & 0.38 & 0.29 & $2 \cdot 5$ & $2 \cdot I$ & 0.84 \\
\hline 0.15 & $2 \cdot 8$ & 3.70 & 0.07 & 0.37 & 0.40 & $2 \cdot 7$ & $2 \cdot 3$ & 0.85 \\
\hline $0 \cdot 17$ & $2 \cdot 8$ & 3.85 & 0.03 & 0.39 & 0.44 & $2 \cdot 8$ & $2 \cdot 3$ & 0.82 \\
\hline 0.22 & $2 \cdot 8$ & 3.80 & 0.12 & 0.38 & 0.58 & $3 \cdot 0$ & $2 \cdot 4$ & 0.80 \\
\hline 0.24 & $2 \cdot 9$ & 3.85 & 0.01 & 0.39 & $0.6 \mathrm{I}$ & $3 \cdot 2$ & 2.5 & 0.79 \\
\hline 0.27 & 3.0 & 3.75 & 0.09 & 0.38 & $0.7 \mathrm{I}$ & $3 \cdot 4$ & $2 \cdot 6$ & 0.77 \\
\hline 0.30 & $3 \cdot \mathrm{I}$ & 3.80 & 0.05 & 0.38 & 0.79 & 3.6 & $2 \cdot 7$ & 0.75 \\
\hline 0.33 & $3 \cdot I$ & 3.00 & 2.65 & 0.40 & 0.82 & $3 \cdot 3$ & $2 \cdot 7$ & 0.82 \\
\hline 0.35 & $4 \cdot 8$ & 0.85 & $7 \cdot 80$ & 0.39 & 0.90 & $2 \cdot 9$ & 3.0 & $\mathrm{I} \cdot 02$ \\
\hline
\end{tabular}

Table 3. Growth characteristics of C. albicans grown on lactate in continuous culture

Culture medium was as described in the text for lactate-limited growth. Steady-state values for dry matter $(X)$, lactate $(S)$, yield $(Y)$, specific oxygen uptake $\left(Q_{\mathrm{O}_{2}}\right.$ in $\left.\mathrm{mmol} \mathrm{O} \mathrm{O}_{2} \mathrm{~g}^{-1} \mathrm{~h}^{-1}\right)$, specific carbon dioxide release $\left(Q_{\mathrm{CO}_{2}}\right.$ in $\left.\mathrm{mmol} \mathrm{CO}_{2} \mathrm{~g}^{-1} \mathrm{~h}^{-1}\right)$, respiration quotient (RQ) and the specific rate of lactate utilization $\left[Q_{\text {lactate }}\right.$ in $\mathbf{g}(\mathrm{g} \text { dry wt) })^{-1} \mathrm{~h}^{-1}$ ] are given as a function of the dilution rate $D$.

\begin{tabular}{|c|c|c|c|c|c|c|c|c|}
\hline$\underset{\left(\mathrm{h}^{-1}\right)}{D}$ & $\begin{array}{c}\text { Final } \\
\mathrm{pH}\end{array}$ & $\begin{array}{c}X \\
(\mathrm{~g} / 1)\end{array}$ & $\underset{(\mathrm{g} / \mathrm{l})}{S}$ & $\begin{array}{c}Y \\
\left(X \mid S_{0}-S\right)\end{array}$ & $Q_{\text {lactate }}$ & $Q_{0_{2}}$ & $Q_{\mathrm{co}_{2}}$ & $\mathrm{RQ}$ \\
\hline 0.02 & $8 \cdot 0$ & 0.60 & 0.10 & $0.2 \mathrm{I}$ & 0.09 & I 6 & $\mathrm{I} \cdot 7$ & I.05 \\
\hline 0.05 & $7 \cdot 3$ & 0.66 & 0.05 & 0.22 & 0.23 & $I \cdot 9$ & $I \cdot 9$ & $\mathrm{I} \cdot \mathrm{OO}$ \\
\hline 0.06 & $7 \cdot 2$ & 0.66 & 0.08 & 0.23 & 0.26 & $2 \cdot 2$ & $2 \cdot 2$ & 0.98 \\
\hline 0.09 & $6 \cdot 9$ & 0.68 & 0.06 & 0.23 & 0.37 & $2 \cdot 5$ & $2 \cdot 3$ & 0.94 \\
\hline 0.10 & 6.8 & 0.69 & 0.04 & 0.23 & $0.4 \mathrm{I}$ & $2 \cdot 6$ & $2 \cdot 4$ & 0.92 \\
\hline 0.12 & $6 \cdot 3$ & 0.66 & 0.07 & 0.22 & 0.54 & $2 \cdot 8$ & 2.5 & .89 \\
\hline 0.13 & $6 \cdot 3$ & 0.68 & 0.05 & 0.23 & 0.56 & $3 \cdot \mathrm{I}$ & $2 \cdot 7$ & 0.87 \\
\hline 0.14 & 6.0 & 0.67 & 0.12 & 0.23 & $0.6 \mathrm{I}$ & $3 \cdot 2$ & $2 \cdot 8$ & 0.86 \\
\hline $0 \cdot 16$ & 6.0 & 0.66 & 0.20 & 0.23 & $0 \cdot 70$ & $3 \cdot 3$ & $2 \cdot 8$ & 0.85 \\
\hline O. I 8 & $5 \cdot 9$ & 0.60 & 0.42 & 0.23 & 0.78 & 3.0 & $2 \cdot 9$ & 0.96 \\
\hline 0.19 & $5 \cdot 7$ & 0.25 & I $\cdot 90$ & 0.23 & 0.82 & 2.6 & 3.0 & $I \cdot I 5$ \\
\hline
\end{tabular}

growth on maltose or the yeast culture resulting from growth on lactate, a mixed morphology, typical of growth on glucose, was obtained.

Cysteine was added to a steady-state glucose-limiting system $\left(\mu 0^{\circ} \mathrm{I}, \mathrm{pH} 5^{\circ} \mathrm{O}\right.$, dry weight $2 \cdot 2 \mathrm{~g} / \mathrm{l})$ at $8 \mathrm{~h}$ intervals for $48 \mathrm{~h}$ to a final concentration of $10 \mathrm{~mm}$. At the end of this period the dry weight was $0.4 \mathrm{~g} / \mathrm{l}$ but there was no change in morphology.

The growth characteristics of $C$. albicans CMI45,348 grown on maltose and lactate in continuous culture are summarized in Tables 2 and 3 and Fig. 2. The $\mu_{\max }$ values of 0.34 (maltose) and $0 \cdot 18$ (lactate) were obtained using wash-out curves. Nickerson \& Chung (1954) found that $C$. albicans ATCCIO26I (which grew predominantly as a yeast form) and a filamentous mutant derived from this strain had similar growth rates in batch cultures on GGY medium. It is not valid, however, to compare these results with the present findings, $\mathrm{n}$ which the different morphological forms were obtained with different carbon sources in continuous culture. 

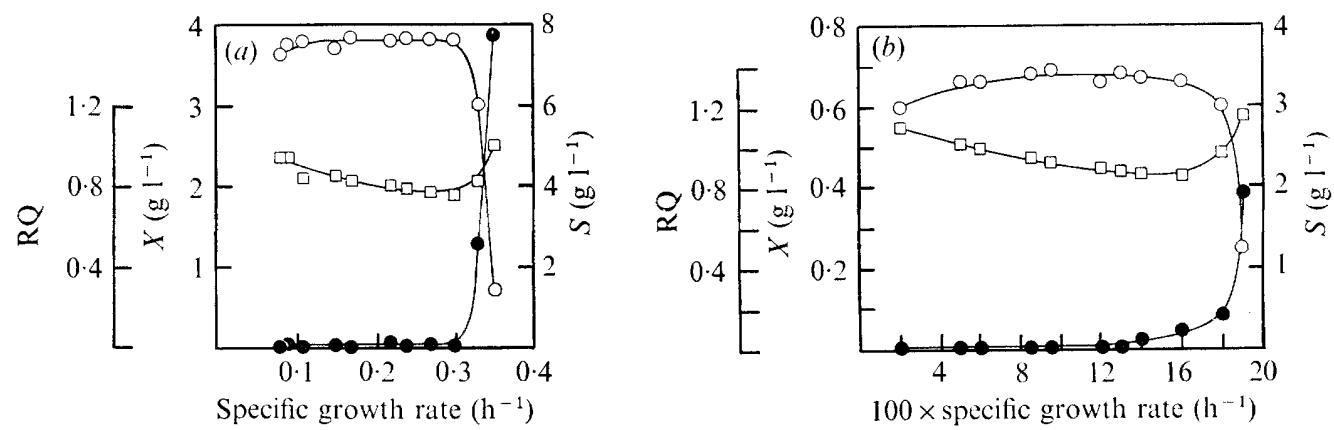

Fig. 2. Growth and metabolism of $C$. albicans CMI45,348 in continuous culture. The culture conditions are described in the text. Steady-state values for $(\bigcirc)$ dry matter $(X)$, $(\bullet)$ substrate concentration $(S)$, and $(\square)$ respiration quotient $(\mathrm{RQ})$ are shown as a function of the specific growth rate $(\mu)$. (a) Growth on maltose; (b) growth on lactate.
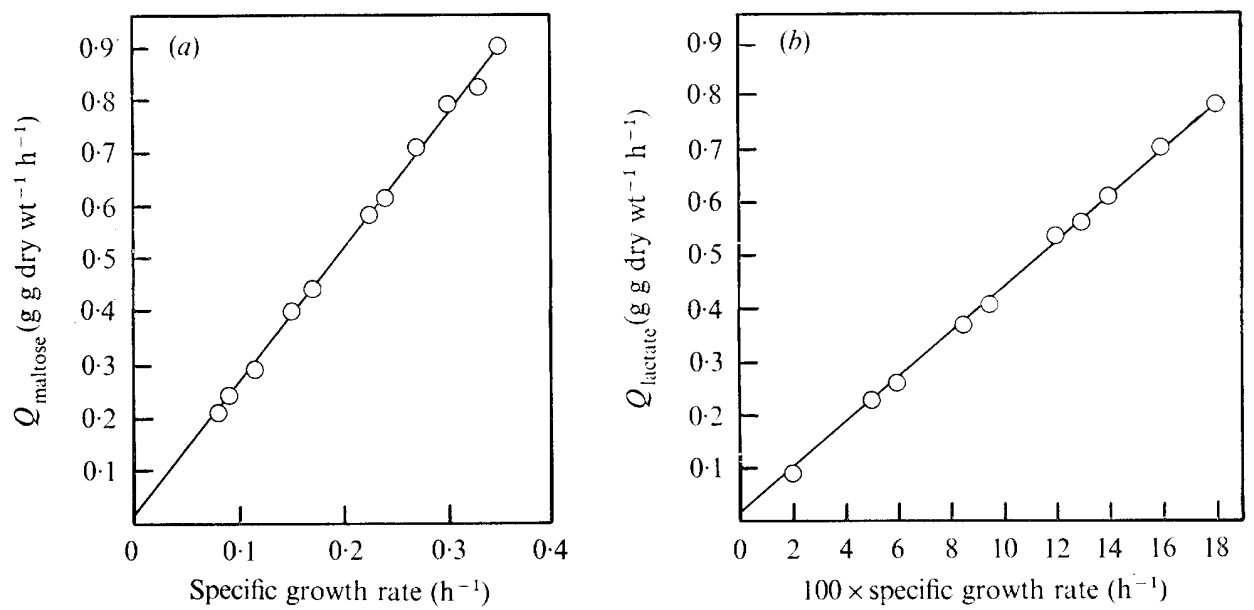

Fig. 3. Effect of the specific growth rate $(\mu)$ on the specific rate of substrate utilization $Q_{\text {substrate }}$ of mycelial and yeast forms of $C$. albicans CMI45,348. $Q_{\text {substrate }}$ values were determined from the relationship $\mu / Y$. (a) Growth on maltose; $(b)$ growth on lactate.

The energy-balance equation derived by Pirt (I965) for cell growth is:

$$
\frac{\mathrm{I}}{Y_{\mathrm{x} / \mathrm{s}}}=\frac{m}{\mu}+\frac{\mathrm{I}}{Y_{\mathrm{s}}}
$$

where $Y_{x / s}$ is the observed growth yield (g cells/g substrate); $\mu$ is the specific growth rate $\left(\mathrm{h}^{-1}\right) ; m$ is the maintenance coefficient $\left[\mathrm{g}\right.$ substrate $(\mathrm{g} \text { cells })^{-1} \mathrm{~h}^{-1}$ ] and $Y_{\mathrm{s}}$ is the true growth yield ( $\mathrm{g}$ cells/g substrate). This equation can be rearranged to:

$$
Q_{\text {substrate }}=m+\frac{\mu}{Y_{\mathrm{s}}},
$$

where $Q_{\text {substrate }}$ is the specific rate of substrate utilization $\mu / Y_{x / \mathrm{s}}$ [g substrate $\mathrm{g}\left(\right.$ dry $\mathrm{wt}^{-1}$ ) $\mathrm{h}^{-1}$. Plots of $Q_{\text {maltose }}$ versus $\mu$ and of $Q_{\text {lactate }}$ versus $\mu$ are given in Fig. 3. Substrate maintenance coefficients of 0.015 and 0.020 were found for maltose and lactate respectively. 

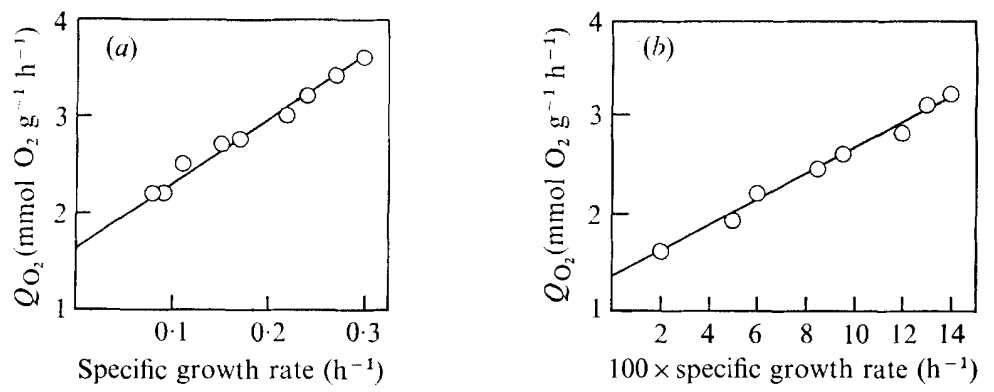

Fig. 4. Effect of the specific growth rate $(\mu)$ on the specific oxygen uptake rate $\left(Q_{o_{2}}\right)$ of mycelial and yeast forms of $C$. albicans CMI45,348. $Q_{\mathrm{O}_{2}}$ values were determined as described in the text. (a) Growth on maltose; $(b)$ growth on lactate.

These values can be compared with the values of 0.018 for Aspergillus nidulans grown aerobically on glucose-limited cultures at $30^{\circ} \mathrm{C}$ (Carter et al., I97I) and 0.022 for Penicillium chrysogenum growing aerobically in a glucose-limited culture at $30^{\circ} \mathrm{C}$ (Righelato et al., 1968).

From Fig. 3, true growth yields of 0.39 (maltose) and 0.25 (lactose) were obtained. These values are low when compared with values of 0.58 for glycerol-limited growth of Torulopsis utilis (Clegg \& Light, 197I), 0.50 for glucose-limited growth of S. cerevisiae (von Meyenburg, 1969) and 0.5I for growth of Candida utilis on glucose (Johnson, I969). However, growth yields of 0.45 for glucose-limited growth of $P$. chrysogenum (Righelato et al., 1968) and 0.38 for C. utilis grown on acetate (Johnson, 1969) have been observed.

Analogous to eqn (2), the specific respiration rate can be described in terms of maintenance and growth (Pirt, I965):

$$
Q_{\mathrm{o}_{2}}=m_{0}+\frac{\mu}{Y_{\mathrm{Go}}}
$$

where $m_{0}$ is the maintenance coefficient for respiration [mmol $\left.\mathrm{O}_{2}(\mathrm{~g} \text { cells })^{-1} \mathrm{~h}^{-1}\right]$ and $Y_{\mathrm{Go}}$ is the true growth yield for oxygen ( $\mathrm{g}$ cells $/ \mathrm{mol} \mathrm{O}_{2}$ ). From Fig. 4, oxygen maintenance coefficients $\left(m_{0}\right)$ of $\mathrm{I} \cdot 65$ and $\mathrm{I} \cdot 35$ were obtained for maltose and lactate. It is not clear why the $m_{0}$ values for $C$. albicans are so much higher than the $m_{0}$ values of 0.55 for $A$. nidulans (Carter et al., I971), and 0.74 for $P$. chrysogenum (Righelato et al., I968). However, the much larger values of 5.5 for Azotobacter vinelandii (Nagai \& Aiba, 1972) and 3.4 for Aerobacter aerogenes (Herbert, 1958) have been reported.

\section{DISCUSSION}

Although there are many reports in the literature on how to induce the yeast-mycelial transformation in $C$. albicans we have had difficulty in obtaining a reproducible method using batch cultures, whereas a chemostat offered several advantages. The medium was a synthetic one, the conditions of growth were reproducible, and large supplies of cells could be obtained for biochemical assays. The observation that maltose favoured the production of mycelial forms supports the reports of Marriott (I975) and Nickerson \& Mankowski (I953) that starch promotes mycelial production in batch cultures of $C$. albicans. Unlike Marriott, however, we did not find that phosphate affected the morphology; a chemostat run with glucose as a carbon source but with limiting phosphate gave a mixed morphology regardless of the dilution rate. A number of strains of $C$. albicans did not produce yeast and mycelial cells in the chemostat; for example $C$. albicans ATCCI026I formed yeast cells regardless of the carbon source. 
An obvious difference in the lactate and maltose growth characteristics is the final $\mathrm{pH}$ of the culture. With lactate the $\mathrm{pH}$ of the medium increased to $\mathrm{pH} 8.0(\mu=0.02)$ from the original value of $\mathrm{pH} 5.8$ (Table 3 ), while with maltose the $\mathrm{pH}$ dropped to $\mathrm{pH} 2.7$ with $\mu$ equal to 0.08 (Table 2). This drop in $\mathrm{pH}$ was found when $C$. albicans was grown on any sugar and was a characteristic feature of all strains of $C$. albicans tested.

With both lactate- and maltose-limited growth, the yield constant $Y$ varied over a range of specific growth rates (Fig. 2). It is believed that the decrease in $Y$ at low dilution rates is because endogenous metabolism becomes a higher proportion of the total metabolism (Mor \& Fiechter, 1968). On approaching the critical dilution rate there is again a decrease in yield. This behaviour is typical of yeast cultures (Aiba, Humphrey \& Millis, 1973) and shows that the assumption that the yield coefficient is independent of the specific growth rate is probably not valid. The rate of transfer of substrate carbon to yeast cells could be of importance in explaining this phenomenon.

That the maltose $m_{0}$ value was higher than the lactate $m_{0}$ value $(\mathrm{I} \cdot 65$ as against $\mathrm{I} \cdot 35)$ could be due in part to the energy requirement of the maltose culture in keeping the intracellular $\mathrm{pH}$ greater than the extracellular level of approximately 2.8 (Table 2 ). If this was so, however, it might be expected that the substrate maintenance coefficient for maltose would be larger than for lactate. The very large oxygen maintenance coefficient may be a reflexion of the nature of respiration for this organism. Firstly, the number of energy coupling sites in the mitochondria of $C$. albicans could be less than three. Secondly, there is present in $C$. albicans (unpublished results) the type of NADH shunt that exists in T. utilis (Light \& Garland, I97I) which would utilize oxygen with a P/O ratio of I. Finally, we have detected in C. albicans an active cyanide-insensitive respiration (Chin, Shepherd \& Sullivan, 1975) which is present in both lactate and maltose cultures. Whether this alternative respiration has any function in the physiological state of $C$. albicans remains to be determined. The large oxygen maintenance coefficient observed for glucose-limited cultures of Azobacter vinelandii was explained in terms of uncoupled growth (Nagai \& Aiba, i972).

An interesting aspect of Tables 2 and 3 was that with both maltose and lactate the respiration quotient decreased with increasing specific growth rate. It would appear that the intermediary metabolism is influenced by the growth rate of the organism. One explanation for the decrease in respiration quotient would be that, as the growth rate increased, intermediary metabolites which are more oxidized than the substrate either accumulated or were used in biosynthetic pathways. As a consequence, the $\mathrm{CO}_{2}$ evolved would decrease relative to the oxygen utilized. The decrease in respiration quotient with increasing growth rate also implies that the catabolism of maltose and lactate to $\mathrm{CO}_{2}$ is less efficient at higher than at lower growth rates. Liener \& Buchanan (195I) reported that $S$. cerevisiae is able to satisfy up to $5 \%$ of its carbon requirements by $\mathrm{CO}_{2}$ assimilation, and Wang et al. (I956) proposed that up to $10 \%$ of the pyruvate originating from glucose was involved in $\mathrm{CO}_{2}$ fixation. It could well be that as the growth rate increased the importance of $\mathrm{CO}_{2}$ fixation reactions increased. It remains to be established whether there is any relationship between the change in respiration quotient with growth rate and the change in yield factor with growth rate. A decrease in respiration quotient with growth rate has also been observed with $S$. cerevisiae in continuous culture (Mor \& Fiechter, 1968).

We are grateful to Mrs S. E. Latimer for technical assistance. This work was supported in part by a grant from the Medical Research Council of New Zealand. 


\section{REFERENCES}

Aiba, S., Hưmprey, A. E. \& Millis, N. F. (1973). Biochemical Engineering. New York and London: Academic Press.

Ballentine, R. (1957). Determination of total nitrogen and ammonia. In Methods of Enzymology, vol. 3, pp. 984-995. Edited by S. P. Colowick and N. O. Kaplan. New York: Academic Press.

BARker, S. (1957). Preparation and colorimetric determination of lactic acid. In Methods in Enzymology, vol. 3, pp. 24I-246. Edited by S. P. Colowick and N. O. Kaplan. New York: Academic Press.

Bartnicki-Garcia, S. \& McMurrough, I. (I97I). Biochemistry of morphogenesis in yeasts. In The Yeasts, vol. 2, pp. 44I-49I. Edited by A. H. Rose and J. S. Harrison. New York and London: Academic Press.

BartniCKi-Garcia, S. \& NiCkerson, W. J. (1962). Nutrition, growth and morphogenesis of Mucor rouxii. Journal of Bacteriology 84, 84I-858.

Brown, C. M. \& Hough, J. S. (1965). Elongation of yeast cells in continuous culture. Nature, London 206, $676-678$.

Carter, B. L. A., Bull, A. T., Pirt, S. J. \& Rowley, B. I. (197I). Relationship between energy substrate utilization and specific growth rate in Aspergillus nidulans. Journal of Bacteriology ro8, 309-3I3.

Chattaway, F. W., Holmes, M. R. \& Barlow, A. J. E. (I968). Cell wall composition of mycelial and blastospore forms of Candida albicans. Journal of General Microbiology 51, 367-376.

Chattaway, F. W., Bishop, R., Holmes, M. R., Odds, F. C. \& Barlow, A. J. E. (I973). Enzyme activities associated with carbohydrate synthesis and breakdown in the yeast and mycelial forms of Candida albicans. Journal of General Microbiology 75, 77-109.

Chin, C. M., Shepherd, M. G. \& Sullivan, P. A. (1975). Cyanide insensitive respiration in Candida albicans. Proceedings of the University of Otago Medical School 53, 42-43.

ClegG, R. A. \& LIGHT, A. P. (I97I). Growth yields of Torulopsis utilis grown in continuous culture with glycerol or iron as the growth-limiting nutrient. Biochemical Journal 124, 152-I 54.

Dabrowa, N., Howard, D. H., Landau, J. W. \& Schehter, Y. (1970). Synthesis of nucleic acids and proteins in dimorphic forms of Candida albicans. Sabouraudia 8, I63-I 69.

Herbert, D. (1958). Some principles of continuous culture. Symposium of the International Congress of Microbiology, no. 6, pp. 381-396.

Johnson, M. J. (I969). Microbial cell yields from various hydrocarbons. In Fermentation Advances, pp. 833842. Edited by D. Perlman. New York and London: Academic Press.

Johnson, M. J., Borkowski, J. \& Engblom, C. (1964). Steam sterilizable probes for dissolved oxygen measurement. Biotechnology and Bioengineering 6, 457-468.

Liener, I. E. \& BuChanAN, D. L. (195I). The fixation of carbon dioxide by growing and non-growing yeast. Journal of Bacteriology 6r, 527-534.

Light, A. P. \& Garland, P. B. (I97I). A comparison of mitochondria from Torulopsis utilis grown in continuous culture with glycerol, iron, ammonium, magnesium or phosphate as the growth-limiting nutrient. Biochemical Journal 124, I 24-I 34.

Lloyd, J. B. \& Whelan, W. J. (1969). An improved method for enzymic determination of glucose in the presence of maltose. Analytical Biochemistry 30, 467-470.

Mardon, D. N., Balish, E. \& Phillips, A. W. (I969). Control of dimorphism in a biochemical variant of Candida albicans. Journal of Bacteriology 100, 70I-707.

MARRIOTT, M. S. (1975). Isolation and chemical characterization of plasma membranes from the yeast and mycelial forms of Candida albicans. Journal of General Microbiology 86, I1 5-1 32.

von Meyenburg, H. K. (1969). Energetics of the budding cycle of Saccharomyces cerevisiae during glucose limited aerobic growth. Archiv für Mikrobiologie 66, 289-303.

Mor, J. R. \& FIECHTER, A. (I968). Continuous cultivation of Saccharomyces cerevisiae. I. Growth on ethanol under steady-state conditions. Biotechnology and Bioengineering 1o, 159-176.

Morris, E. O. (1966). Aggregation of unicells: yeasts. In The Fungi, vol. 2, p. 66. Edited by G. C. Ainsworth and A. S. Sussman. New York and London: Academic Press.

NaGaI, S. \& AiBA, S. (1972). Reassessment of maintenance and energy uncoupling in the growth of Azotobacter vinelandii. Journal of General Microbiology 73, 53 I-538.

Nickerson, W. J. \& MANKowski, Z. (I953). Role of nutrition in the maintenance of yeast shape in Candida. American Journal of Botany 40, 584-592.

Nickerson, W. J. \& Chung, C. W. (1954). Genetic block in the cellular division mechanism of a morphological mutant of a yeast. American Journal of Botany 4r, I I 4-1 20.

Pettersson, G. \& Porath, J. (I966). A cellulolytic enzyme from Penicillium notatum. In Methods in Enzymology, vol. 8, pp. 603-607. Edited by S. P. Colowick and N. O. Kaplan. New York: Academic Press.

PIRT, S. J. (1965). The maintenance energy of bacteria in growing cultures. Proceedings of the Royal Society $B$ I63, 224-23I.

Righelato, R. C. R., Trinci, A. P. J., Pirt, S. J. \& Peat, A. (1968). The influence of maintenance energy and growth rate on the metabolic activity, morphology and conidiation of Penicillium chrysogenum. Journal of General Microbiology 50, 399-412. 
Romano, A. H. (1966). Dimorphism. In The Fungi, vol. 3, pp. 181-209. Edited by G. C. Ainsworth and A. S. Sussman. New York and London: Academic Press.

SimonetTI, N., STRIPPOLI, V. \& CASSONE, A. (1974). Yeast-mycelial conversion induced by $N$-acetyl-Dglucosamine in Candida albicans. Nature, London 250, 344-346.

TASChDJian, C. L., Burchall, J. J. \& KozinN, P. J. (I960). Rapid identification of Candida albicans by filamentation on serum and serum substitutes. Journal of Diseases of Children 99, 21 2-21 5.

Terenzi, H. F. \& Storck, R. (1968). Stimulation by phenethyl alcohol of aerobic fermentation in Mucor rouxii. Biochemical and Biophysical Research Communications 30, 447-452.

Wang, C. H., GregG, C. T., Forbusch, I. A., Christensen, B. E. \& Chedelin, V. H. (1956). Carbohydrate metabolism in baker's yeast. I. Time course study of glucose utilization. Journal of the American Chemical Society 78, 1869-1872.

WARD, J. M. \& NICKERSON, W. J. (I958). Respiratory metabolism of normal and divisionless strains of Candida albicans. Journal of General Physiology 4I, 703-724.

Yamaguchi, H. (1974). Dimorphism in Candida albicans. I. Morphology dependent changes in cellular content of macromolecules and respiratory activity. Journal of General and Applied Microbiology 20, $87-99$. 